\title{
A SEROEPIDEMIOLOGICAL SURVEY OF CHAGAS' DISEASE AND A SEARCH FOR RESERVOIR HOSTS IN TWO ENDEMIC AREAS OF ECUADOR
}

\author{
Tatsuyuki Mimori ${ }^{1}$, Masato Kawabata ${ }^{2}$, Eduardo Gomez ${ }^{3}$, \\ Vigenta Vera de Coronel ${ }^{3}$, Maria de Aroca ${ }^{3}$, \\ Teresa Flor ${ }^{3}$ and Yoshihisa Hashiguchi ${ }^{4}$ \\ Received July 16 1985/Accepted August 201985
}

\begin{abstract}
In two Ecuadorian endemic areas of Chagas' disease, Pedro Carbo in coastal low-land and Zaruma in high-land of the Andes, a seroepidemiological survey of the human infection and a search for reservoir hosts were performed during the period between June 1983 and March 1984.

Indirect hemaggultination (IHA) test-positive rate of inhabitants was 4.3 per cent $(10 / 233)$ in Pedro Carbo, and 15.5 per cent $(67 / 433)$ in Zaruma. The positive rate of high school students was 2.2 per cent $(10 / 446)$ and 3.9 per cent $(12 / 305)$ in each area, respectively.

Trypanosoma cruzi was found in two species of peridomestic mammals, Didelphis marsupialis (opossum) and Dasypus novemcinctus (armadillo). The infection rate of D. marsupialis was 25.0 per cent (17/68) in Pedro Carbo and 18.5 per cent (5/27) in Zaruma. Only one of the 70 babies from pouch of $D$. marsupialis examined was found to be positive for $T$.cruzi, though the mother and the other litter mates were negative for the flagellata. One of four D. novemcinctus was positive for the parasite in Zaruma. No trypanosome was recognized in all the rodents and bats examined. The result suggests that D. marsupialis is the principal reservoir host of Chagas' disease in various endemic areas of Ecuador.
\end{abstract}

\section{INTRODUCTION}

American trypanosomiasis, Chagas' disease, caused by Trypanosoma cruzi is widely found between latitudes $40^{\circ} \mathrm{N}$ and $40^{\circ} \mathrm{S}$ in South and Central Americas and some of the southern states of the United States of America (Molyneux and Ashford, 1983). In Ecuador, several workers reported previously that Chagas' disease spread to various departments of the country from coastal regions to high-lands of the Andes, where it displayed a great problem of public health (Espinoza, 1955; Rodriguez, 1959).

In South and Central Americas, many mammalian orders have already been demonstrated

This study was supported by the Ministry of Public Health, Republic of Ecuador and Japan International Cooperation Agency (JICA).

1 Department of Parasitic Diseases, Kumamoto University School of Medicine, Honjo, Kumamoto 860, Japan; 2 Department of Parasitology National Institute of Health, Kamiosaki, Tokyo 141, Japan; 3 Departamento de Parasitologia, Instituto Nacional de Higiene y Medicina Tropical, Apartado 3961, Guayaquil, Ecuador; 4 Department of Parasitology, Kochi Medical School, Nankoku City, Kochi 781-51, Japan. 
to be the reservoir of T.cruzi, and these animals play an important role in the transmission of Chagas' disease (Zeledón, 1974). However, few investigations have been carried out on the transmission of the disease in Ecuador. Therefore, more precise information on the transmission mode of Chagas' disease has been required in various areas with different endemicity.

We performed a preliminary seroepidemiological survey of the human disease and a search for the reservoir hosts, in two areas, Pedro Carbo and Zaruma, Ecuador. This paper deals with the results of examination on the infection of inhabitants and peridomestic mammals in these areas.

\section{Materials And Methods}

\section{Description of study areas}

Two endemic areas, Pedro Carbo and Zaruma in Ecuador,were chosen as our study areas. The first town, Pedro Carbo, in the Department of Guayas, is situated on the coastal plain of damp ground zone, about $60 \mathrm{~km}$ north-east of Guayaquil, the biggest commercial city in Ecuador. In this area, most of the people live in the houses made of bamboo. The second town, Zaruma, in the Department of El Oro, is located on the mountainous region of the Andes, $1,100 \mathrm{~m}$ above sea level, about $300 \mathrm{~km}$ south-west of Guayaquil. The inhabitants of this town mainly live in brick houses.

\section{Examination of inhabitants}

Serum samples were collected from 679 inhabitants, among which 446 were students of two high schools, Colegio Pedro Carbo and Colegio Granja Garces, in Pedro Carbo, and also collected from 738 inhabitants, among which 305 were students of two high schools, Colegio 26 de Noviembre and Colegio Nocturno San Miguele, in Zaruma. All the serum samples collected were transferred to the laboratory in Guayaquil and then examined by a commercially available kit of indirect hemagglutination (IHA) test (POLYCHACO, S.A.I.C., Argentine) for Chagas' disease. The serum samples thus tested were considered as positive when the reciprocal titer was 16 or more; non of control sera from 32 healthy individuals in non-endemic area for Chagas' disease was reactive at this dilution with this IHA-kit.

\section{Examination of reservoir hosts}

Blood samples of peridomestic mammals, which live surrounding or inner house, including litters of opossum from the pouch of their mothers were examined by culture method. The culture materials were taken from the heart of each mammal by using a disposable syringe with citrate solution. About 0.5 to $3 \mathrm{~m} l$ of each blood sample was overlaid on one to three culture tubes.

\section{Preparation of culture medium}

The culture medium used was modified from Senekjie's medium (Senekjie, 1943), and had been routinely used in the laboratory. The medium was composed of $100 \mathrm{~g}$ beef extract, $1 \mathrm{~g}$ peptone (Difco), $0.5 \mathrm{~g}$ sodium chloride, $2 \mathrm{~g}$ glucose and $2 \mathrm{~g}$ agar (Difco) in $100 \mathrm{~m} l$ distilled water. The $\mathrm{pH}$ was adjusted to $7.2-7.4$ and this stock medium was autoclaved at $120^{\circ} \mathrm{C}$ for 20 minutes. Thereafter, defibrinated sheep blood was added to the melted medium in the rate of 20 per cent, 
and the medium was placed in slant tube. Two $\mathrm{m} l$ sterile physiological saline containing 500 I.U. penicillin and $500 \mu \mathrm{g}$ streptomycin per $\mathrm{m} l$ was overlaid. The inoculated culture tubes were incubated at $25^{\circ} \mathrm{C}$. If no organism was found in the culture until 35 days after incubation, the sample was regarded as negative. The flagellata developed in a test tube were identified as Trypanosoma cruzi by the amastigote proliferation both in mice and in fibroblast cell culture infected with them.

\section{Results}

\section{Serological survey in inhabitants}

The result of a total of 1,417 examinees in the two endemic areas was shown in Table 1. IHA positive inhabitants were observed in 10 (4.3\%) of 233 in Pedro Carbo, and 67 (15.5\%) of 433 in Zaruma. The positive rate of IHA in Zaruma was 3.6 times as much as that in Pedro Carbo. No difference was observed in the positive rate among age groups in Pedro Carbo. In Zaruma, however, positive rate apparently increased with age. There was no difference in the positive rate between males and females in both areas. Positive rate in high school students was 2.2 per cent (10 out of 446) in Pedro Carbo, while it was 3.9 per cent (12 out of 305) in Zaruma.

\section{Examination of reservoir hosts}

As shown in Table 2, T.cruzi was found in two species of peridomestic mammals, Didelphis marsupialis (opossum) and Dasypus novemcinctus (armadillo). The positive rate in D. marsupialis was 25.0 per cent ( 17 out of 68) in Pedro Carbo, and 18.5 per cent (5 out of 27) in Zaruma. No difference was recognized in the positive rate between male and female D. marsupialis (data not

Table 1 Prevalence rate of seropositivity to Trypanosoma cruzi by indirect hemagglutination test in the inhabitants and high school students in Pedro Carbo and Zaruma, Ecuador

\begin{tabular}{|c|c|c|c|c|c|c|c|}
\hline \multirow{3}{*}{$\begin{array}{l}\text { Examinees } \\
\text { 1) Inhabitants } \\
\text { (Age in year) }\end{array}$} & \multicolumn{7}{|c|}{ No. positive*/No. examined } \\
\hline & \multicolumn{4}{|c|}{ Pedro Carbo } & \multicolumn{3}{|c|}{ Zaruma } \\
\hline & \multirow{2}{*}{$\frac{\text { Male }}{0 / 17}$} & \multirow{2}{*}{$\frac{\text { Female }}{2 / 18}$} & \multicolumn{2}{|c|}{ Total $(\%)$} & \multirow{2}{*}{$\frac{\text { Male }}{0 / 1}$} & \multirow{2}{*}{$\frac{\text { Female }}{0 / 3}$} & Total (\%) \\
\hline $0-9$ & & & $2 / 35$ & $(5: 7)$ & & & $0 / 4$ \\
\hline $10-19$ & $1 / 15$ & $0 / 22$ & $1 / 37$ & $(2.7)$ & $1 / 11$ & $0 / 25$ & $1 / 36 \quad(2.8)$ \\
\hline $20-29$ & $2 / 20$ & $2 / 28$ & $4 / 48$ & $(8.3)$ & $0 / 51$ & $7 / 82$ & $7 / 133 \quad(5.3)$ \\
\hline $30-39$ & $0 / 12$ & $1 / 31$ & $1 / 43$ & $(2.3)$ & $3 / 38$ & $4 / 61$ & $7 / 99 \quad(7.1)$ \\
\hline $40-49$ & $2 / 14$ & $0 / 19$ & $2 / 33$ & $(6.1)$ & $3 / 18$ & $8 / 34$ & $11 / 52 \quad(21.2)$ \\
\hline $50-$ & $0 / 19$ & $0 / 18$ & $0 / 37$ & $(0)$ & $23 / 54$ & $18 / 55$ & $41 / 109(37.7)$ \\
\hline Total & $5 / 97$ & $5 / 136$ & $10 / 233$ & $(4.3)$ & $30 / 173$ & $37 / 260$ & $67 / 433(15.5)$ \\
\hline 2) Students** & $5 / 198$ & $5 / 248$ & $10 / 446$ & $(2.2)$ & $8 / 113$ & $4 / 192$ & $12 / 305 \quad(3.9)$ \\
\hline
\end{tabular}

* The test was considered to be positive, when the reciprocal titer was 16 or more.

** 10-19 years old. 
Table 2 Detection of Trypanosoma cruzi by hemoculture method in the blood samples from peridomestic mammals in Pedro Carbo and Zaruma, Ecuador

\begin{tabular}{|c|c|c|c|}
\hline \multicolumn{2}{|r|}{ Mammals examined } & \multirow{2}{*}{$\begin{array}{c}\text { Pedro Carbo } \\
\text { No. positive/ } \\
\text { No. examined }(\%)\end{array}$} & \multirow{2}{*}{ 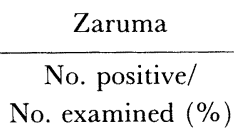 } \\
\hline Order & Species & & \\
\hline \multirow{2}{*}{$\begin{array}{l}\text { Marsupialia } \\
\text { (Opossum) }\end{array}$} & Didelphis marsupialis $\begin{array}{l}\text { (adult) } \\
\text { (baby*) }\end{array}$ & $\begin{array}{r}17 / 68(25.0) \\
1 / 42 \quad(2.4)\end{array}$ & $\begin{array}{lr}5 / 27 & (18.5) \\
0 / 28 & (0)\end{array}$ \\
\hline & Didelphis paraguayensis & - & $0 / 2$ \\
\hline $\begin{array}{l}\text { Edentata } \\
\text { (Armadillo) }\end{array}$ & Dasypus novemcinctus & - & $1 / 4 \quad(25.0)$ \\
\hline \multirow{2}{*}{$\begin{array}{l}\text { Rodentia } \\
\text { (Rodent) }\end{array}$} & Rattus spp. & $0 / 3 \quad(0)$ & $0 / 28$ \\
\hline & Mus musculus & $0 / 62 \quad(0)$ & $0 / 47 \quad(0)$ \\
\hline \multirow{2}{*}{$\begin{array}{l}\text { Chiroptera } \\
\text { (Bat) }\end{array}$} & Molossus molossus & $0 / 72 \quad(0)$ & $0 / 15$ \\
\hline & Artibeus fraterculus & - & $0 / 22 \quad(0)$ \\
\hline
\end{tabular}

* A total of 70 babies derived from 3 positive and 13 negative mothers.

shown). Sixteen females of D. marsupialis from both areas had harboured one to eight litter mates, 70 in total, in their pouches. Only one of these litters was positive for T. cruzi (Table 2). However, the organism was not found in the mother and four brothers of the same litter of the positive D. marsupialis. One out of four D. novemcinctus was positive for T.cruzi in Zaruma. All of 140 rodents and 109 bats were negative for the trypanosome.

\section{Discussion}

We performed a seroepidemiological survey of Chagas' disease in human in Pedro Carbo and Zaruma, Ecuador. Rodorigez (1959) previously reported the prevalence rate of this disease, using complement fixation test (CFT). According to him, the positive rate was 8.8 per cent $(28 / 320)$ in the inhabitants from Department of Guayas, and 22.7 per cent (15/66) in those from Department of El Oro. Moreover, Espinoza (1955) reported that CFT-positive rate in school children was 4.2 per cent $(7 / 167)$ in Guayas and 0.9 per cent $(1 / 109)$ in El Oro. As we detected positive rate of examinees by using IHA, it will be difficult to compare the result directly with previous data. The result, however, suggests that Chagas' disease still remains as a big threat to human health in both endemic areas, Pedro Carbo in Guayas and Zaruma in El Oro, though the prevalence rate was relatively low in the present study.

In Pedro Carbo, there was no difference in the positive rate among age groups of the examinees (Table 1). As this town was located near a big city, Guayaquil, there was a frequent immigration and emigration of people. For this reason, there may be no accumulation of IHA positive persons with age in this region.

In the present study, T.cruzi was found in 22 adult and one baby opossums (D. marsupialis) in both areas examined. T.cruzi was found in opossum captured at Guayas, Ecuador 
(Espinoza, 1953). Moreover, the population size of this species at both collecting sites was considered to be very large at the time of animal collections, suggesting its important role as a reservoir host of Chagas' disease in coastal and mountainous regions of Ecuador.

One baby opossum was positive for T.cruzi in the present examination. This infection might have been caused through post-partum contact with infected vectors, because its mother and brothers were all negative for the trypanosome. Zeledón et al. (1975), during the course of investigation on Chagas' disease, reported negative results in fresh blood examination of 145 young opossums (D.marsupialis) originated from 36 positive mothers in Costa Rica. It was pointed out that young opossums were more susceptible than mature ones to T.cruzi infection which occasionally caused a fatal case (Zeledón and Ponce, 1972). Therefore, judging from the above findings, it seems that congenital infection with T.cruzi is rare in opossum.

In Panama, Rattus rattus was found to be a major reservoir host for Chagas' disease (Edgcomb and Johnson, 1970). In Ecuador, Arzube (1966) demonstrated the presence of rat blood in the gut of Triatoma dimidiata, investigating the blood meal preference of the triatomine bug against various domestic and peridomestic animals. In Colombia, on the other hand, Marinkelle (1982) found T. cruzi infection in bats. In our study, however, the search for T. cruzi in rodents and bats from Pedro Carbo and Zaruma revealed a negative result.

From the present survey of peridomestic mammals, it is likely that opossum plays an important role as reservoir host of Chagas' disease, whereas the other mammals negative for the flagellata such as rats, mice and bats, play rather a minor role in the transmission of human disease in Ecuador.

\section{Acknowledgements}

We are greatly indebted to Dr. Ernesto Gutierz V., Director and Dr. Ramon F. Lazo S., Sub-director of the Instituto Nacional de Higiene y Medicina Tropical (INHMT), Guayaquil, Ecuador. We are grateful to Messrs. Roberto Sud and Miguel Leyton for their untiring efforts in the field examination, and to all the staffs of Departamento de Parasitologia, INHMT for their support during laboratory works. Thanks are also due to Dr. T. Uchida, Faculty of Agriculture, Kyushu University for the identification of bats, Dr. H. Kanbara, Institute for Tropical Medicine, Nagasaki University for the identification of organism, and Dr. I. Tada, Kumamoto University School of Medicine for critical reading of the manuscript.

\section{REFERENCES}

1) Arzube, R. M. A. (1966): Investigación de la fuente alimenticia del T. dimidiata, Later. 1811 (Hemíptera: Reduvidae), mediante la reacción de precipitina, Rev. Ecuat. Hig. Med. Trop., 23, 137-152

2) Edgcomb, J. H. and Johnson, C. M. (1970): Natural infection of Rattus rattus by Trypanosoma cruzi in Panama, Am. J. Trop. Med. Hyg., 19, 767-769

3) Espinoza, L. A. (1953): Algunas consideraciones sobre el comportamiento del Tripanosoma cruzi (Schizo-Trypanum cruzi) en el Didelphis azarae o Didelphis paraguayensis (Zarigüeyas, Zorro común o Raposa), Rev. Ecuat. Hig. Med. Trop., 10, 27-34

4) Espinoza, L. A. (1955): Epidemiología de la enfermedad de Chagas en la República del Ecuador, Rev. Ecuat. Hig. Med. Trop., 12, 25-105

5) Marinkelle, C. J. (1982): Prevalence of Trypanosoma cruzi-like infection of Colombian bats, Ann. 
Trop. Med. Parasit., 76, 125-134

6) Molyneux, D. H. and Ashford, R. W. (1983): The biology of Trypanosoma and Leishmania, parasites of man and domestic animals, Taylor and Francis Ltd., London. pp. 161-182

7) Rodriguez, J. D. (1959): Epidemiología de la enfermedad de Chagas en la República del Ecuador, Rev. Ecuat. Hig. Med. Trop., 16, 158-183

8) Senekjie, H. A. (1943): Biochemical reactions, cultural characteristics and growth requirements of Trypanosoma cruzi, Am. J. Trop. Med., 23, 523-531

9) Zeledón, R. (1974): Epidemiology, modes of transmission and reservoir hosts of Chagas' disease. pp. 51-85 Trypanosomiasis and Leishmaniasis with special reference to Chagas' disease, Ciba Foundation Symposium 20 (new series), Associated Scientific Publishers, Amsterdam

10) Zeledón, R. and Ponce, C. (1972): Neurotropism in Costa Rican strains of Trypanosoma cruzi, J. Parasit., 58, 180-181

11) Zeledón, R., Solano, G., Burstin, L. and Swatzwelder, J. C. (1975): Epidemiological pattern of Chagas' disease in an endemic area of Costa Rica, Am. J. Trop. Med. Hyg., 24, 214-225

\title{
エクアドル共和国のシャーガス病流行地に おける住民及び保虫動物の調査
}

\author{
三森 龍之 ${ }^{1} \cdot$ 川端 眞人 ${ }^{2} \cdot$ E. Gomez ${ }^{3}$ \\ V. Vera de Coronel $^{3} \cdot$ M. de Aroca ${ }^{3}$ \\ T. Flor ${ }^{3} \cdot$ 橋口 義久 ${ }^{4}$
}

エクアドル共和国のシャーガス病流行地の 2 地域, Pedro Carbo (平野部) と Zaruma（標高 $1,100 \mathrm{~m}$ のアンデス山脈中腹部）において，住民の血清学的検査，及び保虫動物の調査を行った。

間接赤血球凝集反応によるシャーガス病陽性率は, 学生を除く住民では, Pedro Carbo で $4.3 \%$ (10/233), Zaruma で15.5\% (67/433) であった。学生の陽性率は, Pedro Carbo で2.2\% (10/446), Zaruma で3.9\% (12/305) であった。

保虫動物の調査において, Trypanosoma cruzi が Didelphis marsupialis (opossum) と Dasypus novemcinctus (armadillo) の 2 種の野性動物から分離された。D. marsupialis の感染率は, Pedro Carbo で25.0\% (17/68)，Zaruma で18.5\% (5/27) であった。D. marsupialis の幼獣70匹のうち 1 匹が陽性であったが, その母獣，及び同腹子からは原虫が確認できなかった。検査した全てのゲッ歯類，及びコウモリは陰 性であった。

これらの結果から, エクアドル共和国においては, D. marsupialis がシャーガス病の主保虫動物と考 えられた。

1 熊本大学医学部寄生虫病学教室 2 国立予防衛生研究所寄生虫部 3 エクアドル国立熱带医学研究 所寄生虫部 4 高知医科大学寄生虫学教室 